\section{Cabbage Yield and Glucosinolate Concentrations as Affected by Nitrogen and Sulfur Fertility}

\author{
C.J. Rosen ${ }^{1}$ \\ University of Minnesota, 1991 Upper Buford Circle, St. Paul, MN 55108
}

\author{
V.A. Fritz ${ }^{2}$ and G.M. Gardner ${ }^{2}$ \\ University of Minnesota, 1790 Folwell Avenue, St. Paul, MN 55108
}

\author{
S.S. Hecht, S.G. Carmella, and P.M. Kenney \\ The Cancer Center, University of Minnesota, St. Paul, MN 55108
}

\begin{abstract}
Glucosinolates are a class of nitrogen (N) and sulfur (S) containing compounds shown to have cancer-preventing properties in animal models and widely found in cruciferous plants. The overall objective of this study was to determine whether $\mathbf{N}$ and $\mathbf{S}$ fertility affects glucosinolate concentrations in cabbage (Brassica oleracea $\mathrm{L}$. Capitata group). Field studies on a sandy soil low in available $N$ and $S$ were conducted over a 2-year period with both green ('Grand Slam') and red ('Vorox') cabbage cultivars. Treatments evaluated each year were the interactive effects of $N\left(125\right.$ and $\left.250 \mathrm{~kg}^{\circ} \cdot \mathrm{ha}^{-1}\right)$ and $S\left(0\right.$, and $\left.110 \mathrm{~kg} \cdot \mathrm{ha}^{-1}\right)$ fertilizer application. Yield of both cabbage cultivars increased with increasing $N$ and $S$ in the second year of the study, but not in the first. Tissue $\mathrm{N}$ concentrations in heads at harvest increased with $\mathbf{N}$ application and tissue $S$ concentrations increased with $S$ application. When $\mathrm{S}$ was not applied, tissue $\mathrm{S}$ decreased significantly as $\mathrm{N}$ rate increased, while $\mathrm{N}$ rate had no effect on tissue $S$ concentrations when $S$ was applied. The dominant glucosinolate detected in both cabbage cultivars was glucobrassicin, with indole forms accounting for about $80 \%$ of the total glucosinolates regardless of treatment. Tissue $\mathbf{N}$ was negatively correlated and tissue $\mathbf{S}$ and $\mathrm{S}$ to $\mathbf{N}$ ratio were positively correlated with total glucosinolate concentration, although all correlations were generally weak $\left(r^{2}<0.5\right)$. Total glucosinolates and glucobrassicin concentrations were maximized in both cultivars at the low $\mathrm{N}$ and high $\mathrm{S}$ application rates. Except for sinigrin in one of the 2 years, all glucosinolates detected were higher in Vorox than in 'Grand Slam'. Based on these results, glucosinolates in cabbage can be manipulated by cultural management practices as well as genetics.
\end{abstract}

Glucosinolates are secondary nitrogen $(\mathrm{N})$ and sulfur $(\mathrm{S})$ containing compounds in plants that have been studied extensively in recent years for their effects on animal health. While glucosinolates are known to be present in 16 families of plants, most of the edible glucosinolate-containing species are found in the family of Cruciferae (Fahey et al., 2001). About 120 glucosinolate compounds have been identified in plants, although there is only limited information on the specific effects of each compound and their breakdown products.

Activity of glucosinolates has been linked to increased insect resistance (Fenwick et al., 1983; Wolfson, 1982) as well as stimulation of insect feeding (Fenwick et al., 1983). The compounds and breakdown products have also been shown to be allelopathic and increase disease resistance of plants (Angus et al., 1994; Bending and Lincoln, 1999; Rosa et al., 1997). When ingested, some glucosinolates have been shown to impart a bitter flavor, cause goitrogenic effects, and reduce meal quality of animal feed(Drewnowski and Gomez-Carneros, 2000; Fenwick et al., 1983).

Received for publication 28 Oct. 2004. Accepted for publication 16 Dec. 2004. This research was conducted with support from the Minnesota Research Fund (formerly the SOTA TEC Fund) and is gratefully acknowledged.

${ }^{1}$ Dept. of Soil, Water, and Climate.

${ }^{2}$ Dept. of Horticultural Science.
One major positive attribute of glucosinolates is that they have been shown to inhibit the activity of some chemical carcinogens. The plant enzyme myrosinase is released upon consumption of glucosinolate containing vegetables and catalyzes glucosinolate hydrolysis (Fenwick et al., 1983). Products of hydrolysis depend on the structure of the glucosinolate. Alkyl and arylalkyl glucosinolates yield mainly isothiocyanates upon myrosinase-catalyzed hydrolysis, whereas indolyl glucosinolates (glucobrassicins) yield primarily indole-3-carbinol or related substituted indole-3-carbinols (Fahey et al., 2001; Fenwick et al., 1989; McDanell et al., 1988). Isothiocyanates as well as indole-3-carbinol are chemopreventive agents against carcinogenesis of the lung and other tissues in laboratory animals, and they exert protective effects such as inhibition of carcinogen activating enzymes, enhancement of carcinogen detoxifying enzymes, and induction of apoptosis (Hecht, 1999). However, indole3-carbinol has also been shown to have tumor promoting activity in animal feeding studies (Fahey and Stephenson, 1999; Hecht, 1999), although results are often conflicting (Fahey et al., 2001). Chemopreventive properties of glucosinolates and their metabolites have been the motivation for recent efforts to better understand factors that affect their production within the plant.

The concentration and chemical form of glucosinolates in plants can be strongly influenced by genotype and environment (Rosa et al., 1997). Of the environmental effects, $S$ and $\mathrm{N}$ fertility have been shown to significantly affect glucosinolate concentration in plant tissue. In an insect feeding study, Brassica nigra (L.) deficient in $\mathrm{S}$ and adequate in $\mathrm{N}$ had lower levels of allyl isothiocyanate and higher levels of feeding by Spodoptera eridiana than plants with low $\mathrm{N}$ and adequate $\mathrm{S}$ (Wolfson, 1982). In oilseed rape (Brassica napus L.), high glucosinolates can reduce meal quality, and studies have shown that high $\mathrm{N}$ and low $\mathrm{S}$ fertility can minimize glucosinolate content of the seed (Zhao et al.,1993,1994). The effect of $\mathrm{N}$ supply on glucosinolates depended on $\mathrm{S}$ supply (Zhao et al., 1993). When soil S was deficient, addition of $\mathrm{N}$ decreased glucosinolate concentration. When soil S was sufficient, addition of N increased glucosinolate concentration or had no effect. Under constant $\mathrm{S}$ supply, increasing $\mathrm{N}$ up to $150 \mathrm{~kg} \cdot \mathrm{ha}^{-1}$ increased seed glucosinolates of oilseed rape, but there was no effect at higher $\mathrm{N}$ rates (Bilsborrow et al., 1993). Decreasing the $\mathrm{N}$ to $\mathrm{S}$ ratio in nutrient solution tended to increase the phenylethyl isothiocyanate concentration (a breakdown product of gluconasturtiin) in watercress plants (Palaniswamy et al., 1995). Similarly, increasing $\mathrm{S}$ fertilization increased glucoraphanin and glucobrassicin concentrations in broccoli florets (Krumbein et al., 2001). In contrast, Vallejo et al. (2003) reported that $S$ fertilization on a clay soil, in general, had no effect on total glucosinolates in edible portions of broccoli. However, in that study, calcium sulfate, which is only sparingly soluble, was used as the $\mathrm{S}$ source, and it was not reported whether the soil used in the study was deficient or low in $\mathrm{S}$ to begin with. Addition of $\mathrm{S}$ fertilizer to a soil already sufficient in $\mathrm{S}$ would not be expected to have significant effects on $\mathrm{S}$ nutrition and glucosinolate synthesis.

Cabbage (Brassica oleracea L. Capitata group) is one of the most widely consumed cruciferous plants in the U.S. (Lucier and Plummer, 2003). However, relatively few studies have been conducted to determine environmental conditions that affect glucosinolate concentrations in edible portions of the cabbage plant. Rosa and Rodrigues (1998) reported that total and individual glucosinolates in root and leaf tissue of cabbage seedlings varied with time of day. Larger variations were found at $30{ }^{\circ} \mathrm{C}$ (stress temperature) compared to $20^{\circ} \mathrm{C}$ (optimum temperature). In a comprehensive review, Rosa et al. (1997) reported that the dominant glucosinolates in white and red cabbage are glucobrassicin and related indole compounds, as well as the aliphatic compounds sinigrin and glucoiberin. Other aliphatic glucosinolates present in red cabbage include glucoraphinin, gluconapin, and gluconapoleiferin. Hecht et al. (2004) reported that glucobrassicans were the major glucosinolates in cabbage as well as other cruciferous vegetables grown in Singapore, accounting for $70 \%$ to $93 \%$ of the total glucosinolates.

Manipulating $\mathrm{N}$ and $\mathrm{S}$ fertility may be one means of altering glucosinolate concentrations and profiles in cabbage and thereby potentially 
increasing health benefits of consuming this vegetable. The overall objective of this study was to determine the effects of $\mathrm{N}$ and $\mathrm{S}$ fertility on yield and glucosinolate concentration profiles of green and red cabbage grown under field conditions.

\section{Materials and Methods}

Field studies were conducted in 2001 and 2002 at the Sand Plain Research Farm in Becker, Minn., on a Hubbard loamy sand soil (sandy, mixed, frigid Entic Hapludolls). This site was selected because of its inherently low background levels of soil N and S. For each growing season, cabbage was planted in different areas within the farm following a previous crop of rye. A factorial treatment arrangement of two cultivars ('Vorox' and 'Grand Slam'), two $\mathrm{S}$ rates $\left(0\right.$ and $\left.110 \mathrm{~kg} \cdot \mathrm{ha}^{-1}\right)$, and two $\mathrm{N}$ rates (125 and $250 \mathrm{~kg} \cdot \mathrm{ha}^{-1}$ ) were tested in all possible combinations each year.

Selected soil properties before planting in 2001-02 were as follows $(0-15 \mathrm{~cm})$ : organic matter, $2.4 \%-2.2 \%$; $\mathrm{pH}$ (1 soil : 1 water) 5.7-6.8; Bray P, 45-44 $\mathrm{mg} \cdot \mathrm{kg}^{-1}$; ammonium acetate extractable $\mathrm{K}, \mathrm{Ca}$, and $\mathrm{Mg}, 108-100$, 527-836, and 81-174 $\mathrm{mg} \cdot \mathrm{kg}^{-1}$, respectively; calcium phosphate extractable $\mathrm{SO}_{4}-\mathrm{S}, 4-5$ $\mathrm{mg} \cdot \mathrm{kg}^{-1}$; DTPA $\mathrm{Zn}, \mathrm{Fe}, \mathrm{Cu}$, and $\mathrm{Mn}, 0.5-0.4$, $34-15,0.5-0.3$, and $9-16 \mathrm{mg} \cdot \mathrm{kg}^{-1}$ respectively; hot water extractable boron, $0.3-0.3 \mathrm{mg} \cdot \mathrm{kg}^{-1}$. Water extractable nitrate- $\mathrm{N}$ in the top $60 \mathrm{~cm}$ of soil in 2001 and 2002 was 15 and $9 \mathrm{~kg} \cdot \mathrm{ha}^{-1}$, respectively. All analyses were carried out using methods described in Dahnke (1988). Before planting in 2001, $18 \mathrm{~kg} \cdot \mathrm{ha}^{-1} \mathrm{~N}, 20$ $\mathrm{kg} \cdot \mathrm{ha}^{-1} \mathrm{P}, 150 \mathrm{~kg} \cdot \mathrm{ha}^{-1} \mathrm{~K}$, and $2.5 \mathrm{~kg} \cdot \mathrm{ha}^{-1} \mathrm{~B}$ and $1100 \mathrm{~kg} \cdot \mathrm{ha}^{-1}$ finely ground dolomitic limestone were applied and then incorporated to a depth of $15 \mathrm{~cm}$ with a field cultivator. Before planting in $2002,20 \mathrm{~kg} \cdot \mathrm{ha}^{-1} \mathrm{P}, 125 \mathrm{~kg} \cdot \mathrm{ha}^{-1} \mathrm{~K}$, and 2.5 $\mathrm{kg} \cdot \mathrm{ha}^{-1} \mathrm{~B}$ were applied and incorporated with a field cultivator. Because $\mathrm{pH}$ was in the optimum range, lime was not needed in 2002.

'Grand Slam' green cabbage and 'Vorox' red cabbage (Jordan Seed, Woodbury, Minn.) were seeded in 50-count transplant flats containing moist soilless seeding media (SunGro Horticulture, SunShine SB-300 Universal, Bellevue, Wash.) and grown in the greenhouse for 5 weeks. Transplants were planted at Becker on 2 July 2001 and 8 July 2002. A transplant solution was prepared with Diazinon AG500 at $0.16 \mathrm{~mL} \cdot \mathrm{L}^{-1}$ water to control root maggots and $11 \mathrm{~N}-21 \mathrm{P}-7 \mathrm{~K}$ at $7 \mathrm{~g} \cdot \mathrm{L}^{-1}$ as a liquid starter fertilizer. About $250 \mathrm{~mL}$ of the solution was applied to the base of the plants after setting in the field. All planting operations were done by hand. Insects and weeds were controlled using standard commercial practices (Foster, 2002).

Four fertilizer treatments tested were 1) $125 \mathrm{~kg} \cdot \mathrm{ha}^{-1} \mathrm{~N}$ and $0 \mathrm{~kg} \cdot \mathrm{ha}^{-1} \mathrm{~S}$; 2) $125 \mathrm{~kg} \cdot \mathrm{ha}^{-1}$ $\mathrm{N}$ and $110 \mathrm{~kg} \cdot \mathrm{ha}^{-1} \mathrm{~S}$; 3) $250 \mathrm{~kg} \cdot \mathrm{ha}^{-1} \mathrm{~N}$ and 0 $\mathrm{kg} \cdot \mathrm{ha}^{-1} \mathrm{~S}$; 4) $250 \mathrm{~kg} \cdot \mathrm{ha}^{-1} \mathrm{~N}$ and $110 \mathrm{~kg} \cdot \mathrm{ha}^{-1}$ $\mathrm{S}$. These rates were selected based on $\mathrm{N}$ and $\mathrm{S}$ fertilizer recommendations of $200 \mathrm{~kg} \cdot \mathrm{ha}^{-1}$ $\mathrm{N}$ and $35 \mathrm{~kg} \cdot \mathrm{ha}^{-1} \mathrm{~S}$ for cabbage in this region (Rosen and Eliason, 1996). Treatments were set out as a split plot design with four replications. Fertilizer was the main plot and cabbage cultivar was the subplot. Each main plot consisted of four rows, $6 \mathrm{~m}$ in length, with the two varieties randomized in the middle of the four rows. The first and fourth rows were border rows. Spacing within rows was $0.45 \mathrm{~m}$ and between rows was $0.9 \mathrm{~m}$. Urea was used as the $\mathrm{N}$ source for the zero $\mathrm{S}$ treatments, and ammonium sulfate was used as the $\mathrm{N}$ and $\mathrm{S}$ source for the $\mathrm{N}$ and $\mathrm{S}$ treatments. Urea was used to equalize $\mathrm{N}$ application as needed in the $\mathrm{N}$ and $\mathrm{S}$ treatments. Nitrogen and S fertilizers were applied in three equal applications at 10 , 17 , and $24 \mathrm{~d}$ after planting in 2001 and 7,15 , and $24 \mathrm{~d}$ after planting in 2002. Because a small amount of $\mathrm{N}\left(18 \mathrm{~kg} \cdot \mathrm{ha}^{-1}\right)$ was applied to all plots in 2001, this amount was subtracted from the sidedress applications so that total $\mathrm{N}$ applied within each treatment and year was the same. Irrigation was applied after each fertilizer application and as needed to prevent water stress.

'Grand Slam' was harvested 4 Sept. 2001 and 17 Sept. 2002. 'Vorox was' harvested 24 Sept. 2001 and 4 Oct. 2002. At harvest, the middle eight heads from each harvest row were cut, trimmed, and weighed. In 2001, one head from each plot was stored at $2{ }^{\circ} \mathrm{C}$ for at most 2 weeks until glucosinolate extraction could be performed. Similar procedures were followed in 2002 except two heads from each plot were stored for glucosinolate extraction. In both years, two additional heads were chopped and then transferred to a forced air dryer set at $60{ }^{\circ} \mathrm{C}$. Dried tissue was ground with a Wiley mill to pass through a $0.4-\mathrm{mm}$ screen and saved for $\mathrm{N}$ and $\mathrm{S}$ determination using combustion techniques (Hern, 1984; Horneck and Miller, 1998).

Glucosinolates were determined using procedures described by Hecht et al. (2004) with slight modifications. For glucosinolate extraction, each head in cold storage was weighed and one quarter of the head was placed into three times the weight per volume of boiling water and boiled for $5 \mathrm{~min}$ to deactivate the myrosinase. The hot cabbage was placed in a blender and ground for two minutes. Aliquots of $100 \mathrm{~mL}$ were stored at $-20^{\circ} \mathrm{C}$ until analysis could be performed. Cabbage blend $(5 \mathrm{~mL})$ was homogenized for 2 min using a Janke-Kundel Turrax T 25 homogenizer set at $12,000 \mathrm{rpm}$, at $4{ }^{\circ} \mathrm{C}$. The homogenate was then centrifuged at $4000 \mathrm{rpm}, 4^{\circ} \mathrm{C}$.

Strong anion exchange (SAX) solid phase extraction cartridges (500 mg, Supelco; Sigma Corp., St. Louis, Mo.) were used to bind the glucosinolates and, after sulfatase treatment, to elute them as desulphoglucosinlates. First, columns were conditioned with $2 \mathrm{~mL}$ of 0.5 M sodium acetate, $\mathrm{pH} 4.6$, followed by $2 \mathrm{~mL}$ of water. Next, $500 \mu \mathrm{L}$ of cabbage supernatant was applied to the SAX columns, followed by $1 \mathrm{~mL}$ of $0.02 \mathrm{M}$ sodium acetate, $\mathrm{pH} 4.0$. Then 3.1 units of sulfatase (S-9626; Sigma) in $1 \mathrm{~mL}$ of water was added, drained to within about $3 \mathrm{~mm}$ of the packing, and allowed to react overnight. The next day, the column was eluted with $3 \mathrm{~mL}$ water and the collected volume was determined by weight. This collection was either analyzed directly by HPLC or stored at $-20^{\circ} \mathrm{C}$ for later analyses. Further washing of the columns showed no desulphated glucosinolates, indicating complete elution. A desulphosinigrin standard curve was made with $0.5 \mathrm{~mL}$ of sinigrin (Cat. \# 85440; Sigma) solutions in water in five concentrations ranging from 0.6 to $12.2 \mu \mathrm{g} \cdot \mathrm{mL}^{-1}$. In total, 0.8 units of the sulfatase was added and allowed to react overnight. The next day, $100 \mu \mathrm{L}$ of acetonitrile was added to stop the reaction, and the enzyme was removed by ultrafiltration through 30,000 MW cut off filters (Amicon filters, cat. \# 4101; Millipore, Bedford, Mass.). The filtered solutions were analyzed by HPLC and the standard curve was constructed.

Analyses were performed on a model 510 pump (Waters Corp., Milford, Mass.), a HP-1100 autosampler (Hewlett-Packard, Wilmington, Del.), and a SPD-10A $v p$ variable wavelength detector (Shimadzu; Wilmington, Del.) set at $\lambda=229 \mathrm{~nm}$. The column was a Luna C18, $5 \mu \mathrm{m}, 250 \times 4.6 \mathrm{~mm}$ (Phenomenex, Torrance, Calif.). The gradient conditions were as follows: solvent $\mathrm{A}=$ water and solvent $\mathrm{B}=$ acetonitrile; 0 to $2 \mathrm{~min}, 5 \% \mathrm{~B}$ to $15 \% \mathrm{~B}$; 2 to $30 \mathrm{~min}, 15 \% \mathrm{~B}$ to $65 \% \mathrm{~B} ; 30$ to $35 \mathrm{~min}, 65 \%$ $\mathrm{B}$ to $90 \% \mathrm{~B} ; 35$ to $37 \mathrm{~min}, 90 \% \mathrm{~B}$ to $5 \% \mathrm{~B}$; and 37 to $60 \mathrm{~min}, 5 \% \mathrm{~B}$. The flow rate was 1.0 $\mathrm{mL} \cdot \mathrm{min}^{-1}$, and $100 \mu \mathrm{L}$ of each sample (the 3 mL SAX collection) was injected.

Data were collected and integrated on Peak Simple software (SRI Instruments, Torrance, Calif.). Desulphated glucosinolates were identified by retention time, using standards kindly provided as a gift from Richard Mithen in Norwich, U.K. The amounts of each desulphated glucosinolate were calculated based on the desulphated sinigrin standard curve and the published UV response factors of the other desulphoglucosinolates relative to the desulphated sinigrin (Official Journal of the European Communities, 1990; Lewis and Fenwick, 1988). The following glucosinolates were consistently detected in cabbage head tissue over the 2-year study: 4-hydroxybutyl (4HOB), progoitrin (PG), glucoraphanin (GR), sinigrin (SN), gluconapin (GNP), 4-hydroxyglucobrassicin(4HOGB), glucobrassicin(GB), 4-methoxyglucobrassicin (4MGB), and 1methoxyglucobrassicin(1MGB). Desulphated glucosinolate peaks were later confirmed by UV spectroscopy using a Waters 996 photodiode array detector.

To monitor precision of the results, aliquots of a large sample of 'Vorox' from the 2001 study was chosen as a quality control reference standard for the 2002 study. The 'Vorox' reference standard was homogenized, aliquots made, stored at $-20^{\circ} \mathrm{C}$ and then included with each set of samples assayed in 2002 . In all cases the level of total glucosinolates in the 'Vorox' reference standard in 2002 was within $15 \%$ of the mean found in 2001. All glucosinolate data are expressed on fresh weight basis. Data for 2001 are based on one head per plot, while in 2002; data are based on the average of two heads per plot.

Testing for significance of year, cultivar, $\mathrm{N}$ rate, $S$ rate, and interactions among effects on all measured variables was done using analysis of variance (ANOVA). Data were analyzed using 
the PROC GLM procedure in SAS (SAS, Cary, N.C). When interactions from ANOVA were significant, LSMEANS was used to determine differences among means within each interaction at the $5 \%$ probability level. Linear correlation and regression analysis were used to examine relationships between tissue concentrations of $\mathrm{N}$ and $\mathrm{S}$ and total glucosinolate concentrations.

\section{Results and Discussion}

Yield response. Cabbage yield response to $\mathrm{N}$ and $\mathrm{S}$ rate depended on year, with the year $\times$ $\mathrm{N}$ rate and year $\times$ S rate interactions significant at the $5 \%$ and $1 \%$ level, respectively (Table 1 ). Yields increased significantly with increasing $\mathrm{N}$ rate in 2002 (30.8 vs. $40.0 \mathrm{Mg} \cdot \mathrm{ha}^{-1}$ ), but not in 2001 (average, $42.0 \mathrm{Mg} \cdot \mathrm{ha}^{-1}$ ). Similarly, yields increased significantly with increasing $\mathrm{S}$ rate in 2002 (32.3 vs. $38.5 \mathrm{Mg} \cdot \mathrm{ha}^{-1}$ ), but not in 2001 (average, $39.8 \mathrm{Mg} \cdot \mathrm{ha}^{-1}$ ). Differences between years in yield response to $\mathrm{N}$ and $\mathrm{S}$ treatments can be explained by differences in rainfall during each growing season. In 2001, total rainfall from planting to harvest was 19.4 $\mathrm{cm}$. The highest event over a $24-\mathrm{h}$ period was $3.0 \mathrm{~cm}$, which occurred $26 \mathrm{~d}$ after transplanting. In contrast, total rainfall in 2002 from planting to harvest was $53.9 \mathrm{~cm}$ with four major leaching events of 5.5, 3.8, 11.9, and $10.5 \mathrm{~cm}$ occurring $3,17,27$, and $59 \mathrm{~d}$ after transplanting, respectively. The water holding capacity within the top $30 \mathrm{~cm}$ on a Hubbard loamy sand ranges from 3 to $4 \mathrm{~cm}$. Because both nitrate and sulfate anions are susceptible to leaching losses, yield response to increasing rates of these nutrients would be expected in years when excessive rainfall occurs, particularly on a sandy soil such as the one used in this study. The year $x$ cultivar interaction was also significant with 'Grand Slam' yields significantly higher than 'Vorox' yields each year, but the difference between the two cultivars was greater in 2002 (44.4 vs. $26.4 \mathrm{Mg} \cdot \mathrm{ha}^{-1}$ ) than in 2001 (45.3

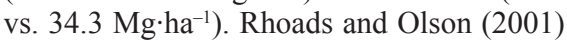
reported that cabbage grown in a low $\mathrm{S}$ soil in Florida responded to $\mathrm{N}$ fertilization only if $\mathrm{S}$ was also applied. This $\mathrm{N} \times \mathrm{S}$ interaction was not observed in the present study and may be due to higher organic matter contents in Minnesota soils compared to Florida soils. Some S may be released during organic matter mineralization.

Tissue nitrogen and sulfur concentrations. Nitrogen concentrations in head tissue at harvest depended on year, variety, $\mathrm{N}$ rate, and $\mathrm{S}$ rate with significant year $\times \mathrm{N}$ rate, year $\times \mathrm{S}$ rate, year $\times$ cultivar, and cultivar $\times \mathrm{N}$ rate interactions (Table 1). Tissue $\mathrm{N}$ concentrations increased significantly with increasing $\mathrm{N}$ rate each year, but the magnitude of response was greater in $2001(2.60 \%$ vs. $3.16 \% \mathrm{~N})$ than in $2002(1.77 \%$ vs. $2.12 \%$ N). Nitrogen concentrations decreased with increasing $\mathrm{S}$ rate in 2001 (3.03\% vs. $2.74 \% \mathrm{~N})$, but were not significantly affected by S rate in 2002 (average, 1.95\% N). 'Vorox' had significantly higher N concentrations than 'Grand Slam' in 2001 (3.11\% vs. $2.66 \% \mathrm{~N}$ ) but significantly lower concentrations than 'Grand Slam' in 2002 (1.77\% vs. $2.12 \% \mathrm{~N})$. Tissue $\mathrm{N}$ concentrations increased with increasing $\mathrm{N}$ rate in both cultivars, but the magnitude of response was greater in 'Grand Slam' $(2.07 \%$ vs. $2.71 \% \mathrm{~N})$ than in 'Vorox' $(2.31 \%$ vs. $2.57 \% \mathrm{~N})$. The generally lower tissue $\mathrm{N}$ concentration in 2002 compared to 2001 was likely due to nitrate losses from excessive rainfall that occurred in 2002. The range of $\mathrm{N}$ concentrations found in head tissue is consistent with a range of $1.82 \%$ to $2.28 \% \mathrm{~N}$ reported by Peck (1981) for cabbage grown with 150 and $300 \mathrm{~kg} \cdot \mathrm{ha}^{-1} \mathrm{~N}$ respectively. Bernard et al. (1990) reported a range of $2.20 \%$ to $2.64 \% \mathrm{~N}$ in head tissue from plants grown with 90 to $270 \mathrm{~kg} \cdot \mathrm{ha}^{-1} \mathrm{~N}$, respectively. Rhoads and Olson (2001) reported ranges of $2.17 \%$ to $2.63 \% \mathrm{~N}$ in head tissue from plants grown with 84 and $168 \mathrm{~kg} \cdot \mathrm{ha}^{-1} \mathrm{~N}$, respectively.

Sulfur concentrations in head tissue at harvest depended on year, variety, and $\mathrm{S}$ rate with significant $\mathrm{N}$ rate $\times \mathrm{S}$ rate, year $\times \mathrm{S}$ rate, year $\times$ cultivar, cultivar $\times \mathrm{N}$ rate, and cultivar $\times \mathrm{S}$ rate interactions. When $\mathrm{S}$ was not applied, tissue $\mathrm{S}$ decreased significantly as $\mathrm{N}$ rate increased from 125 to $250 \mathrm{~kg} \cdot \mathrm{ha}^{-1}(0.57 \% \mathrm{vs}$. $0.48 \% \mathrm{~S}$ ), while $\mathrm{N}$ rate had no effect on tissue $\mathrm{S}$ concentrations when $\mathrm{S}$ was applied (average, $0.74 \%$ ). Tissue $\mathrm{S}$ concentrations increased significantly with increasing $\mathrm{S}$ rate each year, but as with $\mathrm{N}$ concentrations, magnitude of response was greater in $2001(0.66 \%$ vs. $0.95 \%$ S) than in $2002(0.38 \%$ vs. $0.52 \% \mathrm{~S})$. 'Vorox' had significantly higher $\mathrm{S}$ concentrations than 'Grand Slam' in $2001(0.88 \%$ vs. $0.73 \% \mathrm{~S})$, but there were no differences between the two cultivars in 2002 (average, $0.45 \% \mathrm{~S}$ ). Increasing $\mathrm{N}$ rate from 125 to $250 \mathrm{~kg} \cdot \mathrm{ha}^{-1}$ decreased $\mathrm{S}$ concentrations in 'Vorox' $(0.70 \%$ vs. $0.63 \%$ $\mathrm{S})$, but had no effect on 'Grand Slam' (average, $0.59 \%$ S). At the low S rate, 'Grand Slam' had significantly lower tissue S than 'Vorox' $(0.47 \% \mathrm{~S}$ vs. $0.58 \% \mathrm{~S})$, but at the high $\mathrm{S}$ rate, cultivar effects on tissue $\mathrm{S}$ were not significant (average $0.73 \% \mathrm{~S}$ ). The numerous interactions make generalizations difficult to make, but as with $\mathrm{N}$, lower $\mathrm{S}$ concentrations in head tissue in 2002 compared to 2001 were likely due to losses of sulfate through leaching with excessive rainfall in 2002. Bernard et al. (1990) reported a range of $0.74 \%$ to $0.80 \% \mathrm{~S}$ in head tissue from plants grown with grown with 0 $\mathrm{kg} \cdot \mathrm{ha}^{-1} \mathrm{~S}, 180 \mathrm{~kg} \cdot \mathrm{ha}^{-1} \mathrm{~N}$ and $100 \mathrm{~kg} \cdot \mathrm{ha}^{-1} \mathrm{~S}, 180$ $\mathrm{kg} \cdot \mathrm{ha}^{-1} \mathrm{~N}$, respectively. The higher concentration of $\mathrm{S}$ in their $0 \mathrm{~S}$ treatments compared to the present study is likely due to higher initial soil S conditions, although soil test information was not provided in their report. Rhoads and Olson (2001) reported an S concentration of $0.57 \%$ to $0.69 \% \mathrm{~S}$ from plants grown with grown with $0 \mathrm{~kg} \cdot \mathrm{ha}^{-1} \mathrm{~S}, 84 \mathrm{~kg} \cdot \mathrm{ha}^{-1} \mathrm{~N}$ and 22 $\mathrm{kg} \cdot \mathrm{ha}^{-1} \mathrm{~S}, 84 \mathrm{~kg} \cdot \mathrm{ha}^{-1} \mathrm{~N}$, respectively.

Glucosinolate profiles and concentrations. Indole glucosinolates accounted for about $80 \%$ to $85 \%$ of the total glucosinolates measured in both cultivars tested (Table 2). The proportion of indole and aliphatic glucosinolates in head tissue varied with year and was not consistently affected by fertilizer treatment or cultivar. Year $\times$ S rate, year $\times$ cultivar, and year $\times$ cultivar $\times \mathrm{N}$ rate interactions were significant. In 2001, the proportion of indole and aliphatic glucosinolates was not affected by cultivar or $\mathrm{N}$ rate (Table 3 ). However, in 2002, there was a higher proportion of indole glucosinolates and lower proportion of aliphatic glucosinolates in 'Vorox' compared to 'Grand Slam'. In addition, there was no effect of $\mathrm{N}$ rate on the proportion of indole or aliphatic glucosinolates in 'Vorox', but in 'Grand Slam' the proportion of indole glucosinolates

Table 1. Effect of year, cultivar, nitrogen rate, and sulfur rate on cabbage head yield, nitrogen concentrations, and sulfur concentrations.

\begin{tabular}{|c|c|c|c|}
\hline $\begin{array}{l}\text { Source } \\
\text { of } \\
\text { variation }\end{array}$ & $\begin{array}{l}\text { Fresh wt } \\
\left(\mathrm{Mg} \cdot \mathrm{ha}^{-1}\right)\end{array}$ & $\begin{array}{l}\mathrm{N} \\
(\%)\end{array}$ & $\begin{array}{c}\mathrm{S} \\
(\%)\end{array}$ \\
\hline \multicolumn{4}{|l|}{ Year } \\
\hline 2001 & 39.9 & 2.88 & 0.81 \\
\hline 2002 & 35.4 & 1.94 & 0.45 \\
\hline Significance & NS & $* *$ & ** \\
\hline \multicolumn{4}{|l|}{ Cultivar } \\
\hline Grand Slam & 44.8 & 2.39 & 0.59 \\
\hline Vorox & 30.2 & 2.44 & 0.67 \\
\hline Significance & $* *$ & NS & ** \\
\hline \multicolumn{4}{|l|}{$\mathrm{N}$ rate $\left(\mathrm{kg} \cdot \mathrm{ha}^{-1}\right)$} \\
\hline 125 & 34.0 & 2.19 & 0.65 \\
\hline 250 & 41.0 & 2.64 & 0.61 \\
\hline Significance & $* *$ & $* *$ & NS \\
\hline \multicolumn{4}{|l|}{$\mathrm{S}$ rate $\left(\mathrm{kg} \cdot \mathrm{ha}^{-1}\right)$} \\
\hline 0 & 36.1 & 2.50 & 0.52 \\
\hline 110 & 39.2 & 2.33 & 0.74 \\
\hline Significance & NS & $* *$ & ** \\
\hline \multicolumn{4}{|l|}{ Interactions } \\
\hline $\mathrm{N}$ rate $\times \mathrm{S}$ rate & NS & NS & ** \\
\hline Year $\times \mathrm{N}$ rate & $*$ & $*$ & NS \\
\hline Year $\times S$ rate & ** & ** & ** \\
\hline Year $\times \mathrm{N}$ rate $\times \mathrm{S}$ rate & NS & NS & NS \\
\hline Year $\times$ cultivar & $* *$ & ** & ** \\
\hline Cultivar $\times \mathrm{N}$ rate & NS & ** & $*$ \\
\hline Year $\times$ cultivar $\times N$ rate & NS & NS & $*$ \\
\hline Cultivar $\times \mathrm{S}$ rate & NS & NS & NS \\
\hline Year $\times$ cultivar $\times \mathrm{S}$ rate & NS & NS & NS \\
\hline Cultivar $\times \mathrm{N}$ rate $\times \mathrm{S}$ rate & NS & NS & NS \\
\hline Year $\times$ cultivar $\times N$ rate $\times S$ rate & NS & NS & NS \\
\hline
\end{tabular}

NS,****Nonsignificant or significant at $P \leq 0.05$ or 0.01 , respectively. 
Table 2. Effect of year, cultivar, nitrogen rate, and sulfur rate on glucosinolate concentrations in cabbage head tissue at harvest.

\begin{tabular}{|c|c|c|c|c|c|c|c|c|c|c|c|c|}
\hline \multirow{3}{*}{$\begin{array}{l}\text { Source } \\
\text { of } \\
\text { variation }\end{array}$} & \multicolumn{10}{|c|}{ Glucosinolate $^{z}$ concn $(\mu \mathrm{mol} / 100 \mathrm{~g}$ fresh wt) } & \multirow{2}{*}{\multicolumn{2}{|c|}{$\begin{array}{c}\text { Proportion of } \\
\text { glucosinolates } \\
\text { (\% of total) }\end{array}$}} \\
\hline & \multicolumn{5}{|c|}{ Aliphatic } & \multicolumn{4}{|c|}{ Indole } & \multirow[b]{2}{*}{ Total } & & \\
\hline & $4 \mathrm{HOB}$ & PG & GR & SN & GNP & 4HOGB & GB & 4MGB & $1 \mathrm{MGB}$ & & Aliphatic & Indole \\
\hline \multicolumn{13}{|l|}{ Year } \\
\hline 2001 & 14.2 & 1.4 & 4.3 & 13.4 & 2.1 & 5.2 & 173.6 & 22.4 & 14.4 & 251.0 & 13.5 & 86.5 \\
\hline 2002 & 1.8 & 3.7 & 5.3 & 33.5 & 1.8 & 16.2 & 144.8 & 37.3 & 15.1 & 259.5 & 20.0 & 80.0 \\
\hline Significance & $* *$ & $* *$ & NS & $* *$ & NS & $* *$ & NS & $* *$ & NS & NS & $* *$ & $* *$ \\
\hline \multicolumn{13}{|l|}{ Cultivar } \\
\hline Grand Slam & 4.1 & 1.5 & 0.9 & 25.0 & 0.4 & 3.0 & 82.7 & 28.3 & 12.1 & 158.0 & 19.1 & 80.9 \\
\hline Vorox & 11.9 & 3.5 & 8.7 & 21.9 & 3.5 & 18.4 & 235.6 & 31.4 & 17.5 & 352.4 & 14.3 & 85.7 \\
\hline Significance & $* *$ & $* *$ & $* *$ & $*$ & $* *$ & $* *$ & $* *$ & NS & $* *$ & $* *$ & $* *$ & $* *$ \\
\hline \multicolumn{13}{|l|}{$\mathrm{N}$ rate $\left(\mathrm{kg} \cdot \mathrm{ha}^{-1}\right)$} \\
\hline 125 & 9.2 & 2.9 & 5.3 & 25.5 & 2.2 & 9.6 & 180.0 & 31.6 & 17.5 & 283.7 & 17.3 & 82.7 \\
\hline 250 & 6.9 & 2.2 & 4.3 & 21.4 & 1.7 & 11.8 & 138.4 & 28.1 & 12.1 & 226.8 & 16.2 & 83.8 \\
\hline Significance & $* *$ & $*$ & NS & $*$ & $*$ & $*$ & $*$ & NS & * & $*$ & NS & NS \\
\hline \multicolumn{13}{|l|}{$\mathrm{S}$ rate $\left(\mathrm{kg} \cdot \mathrm{ha}^{-1}\right)$} \\
\hline 0 & 7.4 & 2.1 & 3.9 & 20.2 & 1.7 & 10.1 & 137.3 & 29.6 & 13.4 & 225.7 & 16.0 & 84.0 \\
\hline 110 & 8.6 & 3.0 & 5.7 & 26.7 & 2.2 & 11.3 & 181.0 & 30.1 & 16.2 & 284.8 & 17.4 & 82.6 \\
\hline Significance ${ }^{y}$ & NS & $* *$ & $* *$ & $* *$ & $*$ & NS & $*$ & NS & NS & $*$ & NS & NS \\
\hline \multicolumn{13}{|l|}{ Interactions } \\
\hline $\mathrm{N}$ rate $\times \mathrm{S}$ rate & $* *$ & NS & NS & NS & NS & NS & NS & NS & NS & NS & NS & NS \\
\hline Year $\times \mathrm{N}$ rate & $*$ & NS & NS & NS & NS & $* *$ & NS & NS & $*$ & NS & NS & NS \\
\hline Year $\times \mathrm{S}$ rate & NS & $* *$ & $*$ & $* *$ & NS & NS & NS & NS & NS & NS & $*$ & $*$ \\
\hline Year $\times \mathrm{N}$ rate $\times \mathrm{S}$ rate & $*$ & NS & NS & NS & $*$ & $*$ & NS & NS & NS & NS & NS & NS \\
\hline Year $\times$ cultivar & $* *$ & NS & NS & $* *$ & NS & $* *$ & NS & $* *$ & NS & $*$ & $* *$ & $* *$ \\
\hline Cultivar $\times \mathrm{N}$ rate & NS & NS & NS & NS & NS & NS & NS & NS & $*$ & NS & NS & NS \\
\hline Year $\times$ cultivar $\times N$ rate & NS & $*$ & $*$ & $*$ & $*$ & NS & NS & NS & NS & NS & $*$ & $*$ \\
\hline Cultivar $\times \mathrm{S}$ rate & NS & NS & NS & NS & NS & NS & NS & NS & NS & NS & NS & NS \\
\hline Year $\times$ cultivar $\times S$ rate & NS & NS & NS & NS & NS & NS & NS & NS & NS & NS & NS & NS \\
\hline Cultivar $\times \mathrm{N}$ rate $\times \mathrm{S}$ rate & NS & NS & NS & NS & NS & NS & NS & NS & NS & NS & NS & NS \\
\hline Year $\times$ cultivar $\times N$ rate & & & & & & & & & & & & \\
\hline$\times \mathrm{S}$ rate & NS & NS & NS & NS & NS & NS & NS & NS & NS & NS & NS & NS \\
\hline
\end{tabular}

${ }^{\mathrm{z}} \mathrm{HOB}=4$-hydroxybutyl, $\mathrm{PG}=$ progoitrin, $\mathrm{GR}=$ glucoraphanin, $\mathrm{SN}=$ sinigrin, $\mathrm{GNP}=$ gluconapin $(\mathrm{GNP}), 4 \mathrm{HOGB}=4$-hydroxyglucobrassicin, $\mathrm{GB}=$ glucobrassicin $(\mathrm{GB}), 4 \mathrm{MGB}=4$-methoxyglucobrassicin, and $1 \mathrm{MGB}=1$-methoxyglucobrassicin.

NS, ${ }^{*, * *}$ Nonsignificant or significant at $P \leq 0.05$ or 0.01 , respectively.

increased (proportion of aliphatic glucosinolates decreased) with increasing $\mathrm{N}$ rate (Table 3 ). In 2002 , increasing $S$ rate increased the proportion of aliphatic glucosinolates ( $18 \%$ vs. $22 \%$ ) and decreased the proportion of indole glucosinolates ( $82 \%$ vs. $78 \%)$, but in 2001 the effect was not significant $(13 \%$ average for aliphatic and $87 \%$ average for indole glucosinolates). The results in 2002 are similar to those of Zhao et al. (1994). They reported that S application to $\mathrm{S}$ deficient rapeseed plants generally resulted in an increase in the proportion of aliphatic glucosinolates and a decrease in the proportion of indole glucosinolates. They also reported that increasing $\mathrm{N}$ rate increased the proportion of indole glucosinolates relative to aliphatic glucosinolates when $\mathrm{S}$ was deficient, but $\mathrm{N}$ rate had little effect when $\mathrm{S}$ was sufficient. Our study found no effect of $\mathrm{N}$ rate on the proportion of indole and aliphatic glucosinolates with varying $S$ rate.

Total and individual glucosinolate concentrations in cabbage head tissue were variably affected by year, cultivar, $\mathrm{N}$ rate, and $\mathrm{S}$ rate and their interactions (Table 2). Of the individual glucosinolates detected, glucobrassicin was present in highest concentrations and dominated the effects on total glucosinolates. In a study evaluating the effect of sulfur, cultivar, and season on glucosinolate profiles in broccoli, Vallejo et al. (2003) reported numerous interactions among the variables tested on glucosinolate concentrations with indole compounds found in highest concentrations regardless of treatment. Glucobrassicin was found to be the dominant glucosinolate in cabbage by Hecht et al. (2004), but sinigrin was reported to be the dominant glucosinolate by Kushad et al. (1999). Differences in results could be due in part to differences in cabbage cultivars tested. While glucosinolates have been associated with cancer prevention, some have also been associated with bitter taste. Of interest is the observation that taste panelists often associated bitter taste with sinigrin more than glucobrassicin (Drewowski and Gomez-Carneros, 2000). Newer cultivars of Brassica spp. may be lower in sinigrin to reduce bitterness.

Main effects of cultivar, $\mathrm{N}$ rate, and $\mathrm{S}$ rate significantly affected total glucosinolate and glucobrassicin concentrations in head tissue. For total glucosinolates, the year $\times$ cultivar effect was significant, but this was due to differences in magnitude rather than direction. In both years total glucosinolates were lower in 'Grand Slam' than in 'Vorox', but the differences were greater in 2001 (133 vs. 368 $\mu \mathrm{mol} / 100 \mathrm{~g}$ fresh weight) than in 2002 (183 vs. $336 \mu \mathrm{mol} / 100 \mathrm{~g}$ fresh weight). For glucobrassicin, all interactions were nonsignificant as was the effect of year. Averaged over years and fertilizer treatments, 'Vorox' had higher concentrations of glucobrassicin than 'Grand Slam'. Averaged over years, cultivar, and N rate, increasing $\mathrm{S}$ rate significantly increased total glucosinolate and glucobrassicin concentrations. In contrast, when averaged over years, $\mathrm{S}$ rate, and cultivar, increasing $\mathrm{N}$ rate decreased total glucosinolate and glucobrassicin concentrations. Total glucosinolates and glucobrassicin appear to be maximized under conditions of high $\mathrm{S}$ fertility and moderate levels of $\mathrm{N}$ fertility. The effect of increasing glucosinolate concentrations with increasing $\mathrm{S}$ rate is consistent with previous reports on $S$ fertility in a number of cruciferous crops grown on low S soils (Krumbein et al., 2001; Zhao et al., 1993). The decrease in glucosinolates with increasing $\mathrm{N}$ rate is also consistent with previous results on low $\mathrm{S}$ soils, but we did not observe a significant $\mathrm{S}$ rate $\times \mathrm{N}$ rate interaction as reported by Zhao et al. (1993) in oilseed rape. They found that increasing $\mathrm{N}$ rate increased glucosinolates when adequate $\mathrm{S}$ was supplied, but decreased glucosinolates when S supply was deficient. Further studies with cabbage using a wider range of $\mathrm{N}$ and $\mathrm{S}$ rates may be warranted to more clearly determine if a significant $\mathrm{N} \times \mathrm{S}$ interaction exists. In addition, because only one or two heads were sampled per plot in the present study, composite samples of several heads may be warranted in future studies to obtain better representation of each treatment.

Even though total glucosinolate concentrations increased with increasing $\mathrm{S}$ fertilization, the overall relationship between $\mathrm{S}$ concentrations $(\%)$ in head tissue and total glucosinolate concentrations ( $\mu \mathrm{mol} / 100 \mathrm{~g}$ fresh weight) was weak when combined overyears, cultivars, and fertilizer treatments with an $r^{2}$ of 0.04 and a slope of $121(n=64)$. The reason for the lack of correlation was due to a wide disparity in tissue $\mathrm{S}$ over the 2 years. Tissue $\mathrm{S}$ concentrations in 2001 were nearly twice those found 
Table 3. Proportion of aliphatic and indole glucosinolates in cabbage as affected by the year $\times$ cultivar $\times$ nitrogen rate interaction.

\begin{tabular}{llccr}
\hline & \multicolumn{2}{c}{ Variable } & \multicolumn{2}{c}{ Glucosinolate $(\%)$} \\
\cline { 2 - 3 } Year & Cultivar & N rate $\left(\mathrm{kg} \cdot \mathrm{ha}^{-1}\right)$ & & Aliphatic \\
\hline 2001 & Grand Slam & 125 & $11.5 \mathrm{c}^{\mathrm{z}}$ & $88.5 \mathrm{a}$ \\
2001 & Grand Slam & 250 & $11.6 \mathrm{c}$ & $88.4 \mathrm{a}$ \\
2001 & Vorox & 125 & $15.8 \mathrm{c}$ & $84.2 \mathrm{a}$ \\
2001 & Vorox & 250 & $15.0 \mathrm{c}$ & $85.0 \mathrm{a}$ \\
2002 & Grand Slam & 125 & $29.6 \mathrm{a}$ & $70.4 \mathrm{c}$ \\
2002 & Grand Slam & 250 & $23.9 \mathrm{~b}$ & $76.1 \mathrm{~b}$ \\
2002 & Vorox & 125 & $12.1 \mathrm{c}$ & $87.9 \mathrm{a}$ \\
2002 & Vorox & 250 & $14.3 \mathrm{c}$ & $85.7 \mathrm{a}$ \\
\hline
\end{tabular}

${ }^{\mathrm{z}}$ Means within a column followed by the same letter are not significantly different at $P=0.05$.

in 2002, yet total glucosinolate concentrations were similar. Similarly, the overall relationship between total glucosinolate concentrations and $\mathrm{N}$ concentrations was also weak with an $r^{2}$ of 0.01 and a slope of $-22(n=64)$. The relationship between total glucosinolate concentrations and $\mathrm{S}$ to $\mathrm{N}$ ratio was higher than the individual elements with an $r^{2}$ of 0.12 and a slope of 608 $(n=64)$, but was still relatively weak. Stronger relationships between total glucosinolates and tissue $\mathrm{S}, \mathrm{N}$ and $\mathrm{S}$ to $\mathrm{N}$ were obtained when they were calculated using individual cultivars within years (data not presented). All slopes were positive for relationships between total glucosinolates and tissue $\mathrm{S}$ and $\mathrm{S}$ to $\mathrm{N}$ ratios and negative for relationships with tissue $\mathrm{N}$. The highest $r^{2}$ obtained was 0.50 for 'Grand Slam' in 2001 for the relationship between total glucosinolates and $\mathrm{S}$ to $\mathrm{N}$ ratio $(\mathrm{n}=16$, slope of 338 and intercept of 36 ). While some trends were evident, these results suggest that use of tissue $\mathrm{N}$ and $\mathrm{S}$ alone cannot be used to predict total glucosinolate levels in cabbage.

The other indole glucosinolates were present at much lower concentrations than glucobrassicin. 1-Methoxyglucobrassicin concentrations were higher in 'Vorox' than 'Grand Slam' and increasing $\mathrm{N}$ rate from 125 to 250 $\mathrm{kg} \cdot \mathrm{ha}^{-1}$ decreased concentrations in 'Vorox' ( $22 \mathrm{vs} .13 \mu \mathrm{mol} / 100 \mathrm{~g}$ fresh weight), but not in 'Grand Slam' (average, $12 \mu \mathrm{mol} / 100 \mathrm{~g}$ fresh weight). Nitrogen rate also tended to decrease 1MGB concentrations more in 2001 than in 2002 (data not presented). 4-Methoxyglucobrassicin concentrations were higher in 'Vorox' than 'Grand Slam' in 2002 (27 vs. $18 \mu \mathrm{mol} / 100$ $\mathrm{g}$ fresh weight), but both cultivars had similar concentrations in 2001 (average $37 \mu \mathrm{mol} / 100$ $\mathrm{g}$ fresh weight). 4-Hydroxyglucobrassicin concentrations depended on year, $\mathrm{N}$ rate, and cultivar with significant year $\times$ cultivar, year $\times$ $\mathrm{N}$ rate and year $\times \mathrm{N}$ rate $\times \mathrm{S}$ rate interactions. 'Vorox' had higher 4HOGB concentrations than 'Grand Slam' in both years but the magnitude of the differences was greater in 2002 than in 2001 (data not presented). In 2001, N rate had no effect on $4 \mathrm{HOGB}$ concentrations at either S rate. In 2002, 4HOGB increased with increasing $\mathrm{S}$ rate at the high $\mathrm{N}$ rate, but it was not affected by $\mathrm{S}$ rate at the low $\mathrm{N}$ rate (data not presented).

Of the aliphatic glucosinolates, sinigrin was consistently found in highest concentrations over the 2-year study. Sinigrin concentrations were significantly affected by year, cultivar, $\mathrm{N}$ rate, and $\mathrm{S}$ rate with significant year $\times \mathrm{S}$ rate, year $\times$ cultivar, and year $\times$ cultivar $\times \mathrm{N}$ rate interactions. In 2002, 'Grand Slam' had higher concentrations than 'Vorox'. This was the only case where a glucosinolate was found in higher concentrations in 'Grand Slam' than in 'Vorox'. Also in 2002, the higher $\mathrm{N}$ rate resulted in lower $\mathrm{SN}$ concentrations in 'Grand Slam', but N rate had no effect in 'Vorox' (data not presented). In 2001, 'Vorox' had higher SN concentrations than 'Grand Slam' with no effect due to N rate in either cultivar. Sinigrin increased with increasing $\mathrm{S}$ rate in 2002, but was not significantly affected by S rate in 2001 (data not presented). 4-hydroxybutyl glucosinolate was strongly affected by year with higher concentrations found in 2001 compared to 2002. Cultivar effects were only significant in 2001 with higher 4-HOB concentrations found in 'Vorox' compared to 'Grand Slam'. The N rate $\times$ S rate interaction was significant in 2001 but not in 2002. In 2001, increasing $\mathrm{N}$ decreased $4 \mathrm{HOB}$ glucosinolate concentrations at low S (18 vs. 9 $\mu \mathrm{mol} / 100 \mathrm{~g}$ fresh weight) but $\mathrm{N}$ rate had no effect when $S$ was applied (average $15 \mu \mathrm{mol} / 100$ g fresh weight). Glucoraphinin, gluconapin, and progoitrin were present at relatively low concentrations both years and generally followed trends of the other glucosinolates with higher concentrations in 'Vorox' compared to 'Grand Slam' and lowest concentrations with low $\mathrm{S}$ and high $\mathrm{N}$ fertility.

\section{Conclusions}

Cabbage yield increased with $\mathrm{N}$ and $\mathrm{S}$ fertilizer applications in one of the 2 years of the study. The responsive year occurred with excessive rainfall through the growing period. The results of this research clearly demonstrate that glucosinolate concentrations in cabbage grown on a low $\mathrm{S}$ and $\mathrm{N}$ soil can be manipulated by soil fertility and genetics. 'Vorox', a red cabbage, consistently had higher glucosinolate concentrations compared to 'Grand Slam', a green cabbage. Under conditions of this study, indole forms were the dominant glucosinolates detected and maximized at the low $\mathrm{N}$ fertilizer application rate and high $\mathrm{S}$ fertilizer application rate. Interactions between $\mathrm{N}$ and $\mathrm{S}$ fertility on glucosinolate concentrations were not significant; however further studies with cabbage using a wider range of $\mathrm{N}$ and $\mathrm{S}$ rates may be warranted to more clearly determine if a significant $\mathrm{N} \times \mathrm{S}$ interaction exists.

\section{Literature Cited}

Angus, J.F., P.A. Gardner, J.A. Kirkegaard, and
J.M. Desmarchelier. 1994. Biofumigation: Isothiocynates released from Brassica roots inhibit growth of take-all fungus. Plant and Soil. 162:107-112.

Bending, G.D. and S.D. Lincoln. 1999. Characterisation of volatile sulphur containing compounds produced during decomposition of Brassica juncea tissues in soil. Soil Biol. Biochem. 31:695-703.

Berard, L.S., M. Senecal, and B. Vigier. 1990. Effects of nitrogen fertilization on stored cabbage. II. Mineral composition in midrib and head tissues of two cultivars. J. Hort. Sci. 65:409-416.

Bilsborrow, P.E., E.J. Evans, and F.J. Zhao. 1993. The influence of spring nitrogen on yield, yield components and glucosinolate content of autumn sown oilseed rape (Brassica napus). J Agr. Sci. Cambr. 120:219-224.

Dahnke,W.C. 1988. Recommended chemical soil test procedures for the north central region. N.Dak. Agr. Expt. Sta. Bul. 499.

Drewnowski, A. and C. Gomez-Carneros. 2000. Bitter taste, phytonutrients, and the consumer: A review. Amer. J. Clinical Nutr. 72:1424-1435.

Fahey, J.W. and K.K Stephenson. 1999. Cancer chemoprotective effects of cruciferous vegetables. HortScience 34:1159-1163.

Fahey, J.W., A.T. Zalemann, and P. Talalay. 2001. The chemical diversity and distribution of glucosinolates and isothiocynates among plants. Phytochemistry 56:5-51.

Fenwick, G. R., R. K. Heaney, and W. J. Mullin. 1983. Glucosinolates and their break down products in food and food plants. Crit. Rev. Food Sci. Nutr. 18:123-201.

Fenwick, G.R., R.K. Heaney, and R. Mawson. 1989. Glucosinolates, p. 2-41. In: P.R. Cheeke (ed.). Toxicants of plant origin. vol 2. Glycosides. CRC Press, Boca Raton, Fla.

Foster, R. 2002. Midwest vegetable production guide for commercial growers. Univ. Minn. Ext. Serv. BU-07094-S. p. 49-56.

Hecht, S.S. 1999. Anticarcinogenesis by isothiocynates, indole-3-carbinol, and Allium thiols, p. 306-333. Proc. DFG Sympo. Carcinogenic/Anticarcinogenic Factors in Foods: Novel Concepts. Wiley VCH.

Hecht S.S., S.G. Carmella, P.M. Kenney, S. Low, K. Arakawa K, and M.C. Yu . 2004. Effects of cruciferous vegetable consumption on urinary metabolites of the tobacco-specific lung carcinogen 4-(methylnitrosamino)-1-(3-pyridyl)-1-butanone in Singapore Chinese. Cancer Epidemiol. Biomarkers Prev. 13:997-1003.

Hern, J.L. 1984. Determination of total sulfur in plant materials using an automated sulfur analyzer. Commun. Soil Sci. Plant Anal.15:99-107.

Horneck, D.A. and R.O. Miller. 1998. Determination of total nitrogen in plant tissue. In: Y.P. Kalra (ed.). Handbook of reference methods for plant analysis. CRC Press, Boca Raton, Fla.

Krumbein, A., I. Schonhof, J. Ruhlmann, and S. Widell. 2001. Influence of sulphur and nitrogen supply on flavour and health-affecting compounds in Brassicaceae, p. 294-295. In: W.J. Horst et al. (eds). Plant nutrition-Food security and sustainability of agro-ecosystems through basic and applied research. Kluwer, Dordrecht, The Netherlands.

Kushad, M.M., A.F. Brown, A.C. Kurilich, J.A. Juvik, B.P. Klein, M.A. Wallig, and E.H. Jeffery. 1999. Variation in glucosinolates in vegetable crops of Brassica oleracea. J. Agr. Food Chem. 47:1541-1548.

Lewis, J. and G.R. Fenwick. 1988. Glucosinolate content of Brassica vegetables - Chinese cabbages Pe-tsi (Brassica pekinensis) and Pak-choi (Brassica chinensis). J. Sci. Food Agr. 45:379-386. 
Lucier, G. and C. Plummer. 2003. Vegetables and melons outlook. Electronic outlook report from the economic research service. USDA VGS-297. http://www.ers.usda.gov/publications/vgs/ jun03/vgs297.pdf.

McDanell, R., A.E. McLean, A.B. Hanley, R.K. Heaney, and G.R. Fenwick. 1988. Chemical and biological properties of indole glucosinolates (glucobrassicins): A review. Food Chem. Toxicol. 26:57-90.

Official Journal of the European Communities. 1990. L170, 03.07.27-34. Offic. J. Euro. Commun.

Palaniswamy, U., R. McAvoy, B. Bible, S. Singha, and D. Hill. 1995. Phenylethyl isothiocyanate concentration in watercress (Nastutium officinale R.Br.) is altered by the nitrogen and sulfur ratio in hydroponic solution, p. 280-284. In: DL Gustine and HE Flores (eds.). Phytochemicals and Health. Amer. Soc. Plant Physiol.

Peck, N.H. 1981. Cabbage plant responses to nitrogen fertilization. Agon. J. 73:679-684.

Rhoads, F.M. and S.M. Olson. 2001. Cabbage response to sulfur source and nitrogen rate. Soil Crop Sci. Soc. Flla. Proc. 60:37-40.

Rosa, E.A., R.K. Heaney, G.R. Fenwick, and C.A. M. Portas. 1997. Glucosinolates in crop plants. Hort. Rev. 19:99-215.

Rosa, E. A. and P. M. Rodrigues. 1998. The effect of light and temperature on glucosinolate concentration in the leaves and roots of cabbage seedlings. J. Sci. Food Agr. 78:208-212.

Rosen, C.J. and R.D. Eliason. 1996. Nutrient management for commercial fruit and vegetable crops in Minnesota. Univ. Minn. Ext. Ser. Bul. BU-05886.

Vallejo, F., F.A. Tomas-Barberan, A. Gonzalez
Benavente-Garcia and C. Garcia-Viguera. 2003. Total and individual glucosinolate contents in inflorescences of eight broccoli cultivars grown under various climatic and fertilization conditions. J. Sci. Food Agr. 83:307-313.

Wolfson, J.L. 1982. Developmental responses of Pieris rapae and Spodoptera eridania to environmentally induced variation in Brassica nigra. Environ. Entomol. 11:207-213.

Zhao, F., E.J. Evans, P.E. Bilsborrow, and J.K. Syers. 1993. Influence of sulphur and nitrogen on seed yield and quality of low glucosinolate oilseed rape (Brassica napus L). J. Sci. Food Agr. 63:29-37.

Zhao, F., E.J. Evans, P.E. Bilsborrow, and J.K. Syers. 1994. Influence of nitrogen and sulphur on the glucosinolate profile of rapeseed (Brassica napus L). J. Sci. Food Agr. 64:295-304. 